\title{
The European Language Portfolio: Past Success, Present Reality, Future Prospects
}

\author{
David Little (Dublin/Ireland)
}

\section{Introduction}

Portfolio learning and portfolio assessment existed long before the Council of Europe launched the European Language Portfolio, but it was the ELP that introduced portfolio work to mainstream foreign language teaching and learning across Europe. The concept of the ELP was developed through the 1990s in parallel with the Common European Framework of Reference for Languages (CEFR, Council of Europe 2001). In 1997 an intergovernmental conference in Strasbourg was presented with the second draft of the CEFR (Council of Europe 1996) and a set of preliminary ELP studies (Council of Europe 1997). Over the next three years, the CEFR was given its final shape and a network of pilot projects drawn from fifteen Council of Europe member states and four INGOs (international non-governmental organizations) developed and piloted ELPs for learners of all age groups and proficiency levels (Schärer 2000). In 2001 the CEFR was published commercially in English and French, the concept of the ELP was widely disseminated on the basis of Principles and Guidelines (Council of Europe 2000), and competent agencies in the member states were invited to develop ELPs and submit them to the Council of Europe for validation and accreditation.

The CEFR immediately established itself as an indispensable international metric; in particular, its proficiency levels were adopted by the major European language testing agencies. To begin with, the ELP was received with much the same enthusiasm as the CEFR, and over the next decade the Council of Europe 
validated and accredited 118 ELPs from 33 member states and six INGOs. ${ }^{1}$ But while the impact of the CEFR continued to increase steadily, in Europe and beyond (see Byram \& Parmenter 2012), the ELP mostly failed to gain lasting traction. Few of the validated and accredited models were ever used on a large scale, and I have been unable to find evidence of an enduring ELP culture anywhere in Europe.

Besides providing much-needed proficiency levels and illustrative scales, the CEFR crystallizes three decades of Council of Europe work on the policy and practice of foreign language education. The structure and function of the ELP reflect the main focuses of this work, which seem to be little known to the language teaching profession at large. In 2018 the Council of Europe published online a Companion Volume to the CEFR (Council of Europe 2018). Many of the new scales it contains are intended to support the design of language curricula and the development of language teaching. This prompts the question: Is the time ripe for a revival of the ELP as a way of mediating the Council of Europe's ethos, policy and approach to language education professionals and their learners?

The text that follows attempts to answer that question; in doing so it draws on my own experience as researcher, teacher and administrator. I was involved in the development and implementation of ELPs in various educational domains in Ireland; and from 2000 to $2011 \mathrm{I}$ was successively consultant to and member, vice chair and chair of the Council of Europe's ELP Validation Committee. Section 2 summarizes the challenge the CEFR poses to language education and the role the ELP was intended to play in responding to the challenge; section 3 describes the only ELP project I am aware of that for a few years managed to sustain itself at national level; section 4 seeks to explain why the ELP failed to take root in most European education systems; section 5 suggests some of the ways in which the Companion Volume might be used to support a revival of the ELP; and section 6 argues that any revival of the ELP is likely to be on a small scale.

\section{The challenge of the CEFR and the role of the ELP}

\subsection{The alignment of learning, teaching and assessment}

It is widely assumed, especially by those whose knowledge is based only on a reading of the global scale and the self-assessment grid (Council of Europe 2001: 24, 26f.), that the CEFR's purpose is to impose a set of proficiency standards on language education across Europe - an assumption that is no doubt reinforced by the fact that the major European language testing agencies all seek to relate their

\footnotetext{
${ }^{1}$ For details, go to https://www.coe.int/en/web/portfolio/accredited-and-registered-elp [01.03.2019]; see also Little et al. (2011).
} 
tests to the CEFR's common reference levels. But this assumption is false, for two reasons. First, the Council of Europe's role in relation to education in its member states is advisory only; and secondly, in its work on language education the organization involved itself first with learning, then with teaching, and only after that with assessment. This chronological order is reflected in the second half of the CEFR's title: learning, teaching, assessment. The same order of priority is preserved in its discursive treatment of the different dimensions of language education and reflected in its action-oriented approach to the description of language proficiency as language use. The "can do" descriptors of the global scale, self-assessment grid and illustrative scales describe the communicative capacities of an individual learner/user in his or her social context. And it is in this approach to the definition of communicative proficiency that the CEFR's true challenge lies. Each "can do" descriptor can be used at once to define a curriculum goal or intended learning outcome, suggest learning activities and provide a starting point for the development of assessment procedures and instruments. In other words, the CEFR offers to bring curriculum, teaching/learning and assessment into closer interaction than has usually been the case. This means that it can serve as a tool of "constructive alignment” (Biggs \& Tang 2011), a procedure that first defines learning outcomes, then decides how to determine the extent to which those outcomes have been achieved and finally considers what kinds of activity are most likely to bring learners to the desired outcomes (I have explained elsewhere how the CEFR can be used in this way to frame language learning, teaching and assessment at university; see Little 2011, 2012a, 2017a).

According to the theory of constructive alignment, learners should be the agents of their own learning; and learners themselves can share in the assessment culture that the CEFR invites us to develop, thanks to the functional ("can do") orientation of its descriptive scheme. We cannot always gauge accurately what we know, but from a very early age we know what we can do (though not necessarily what we cannot do). The ELP mediates the CEFR's ethos and action-oriented approach to learners via checklists of "I can" descriptors that they use to identify learning targets and assess learning progress. Goal setting and self-assessment are key features of autonomous learning and shape the dynamic of effective ELP use; but when the Principles and Guidelines describe the ELP as "a tool to promote learner autonomy" (Council of Europe 2011: 5), they are referring to an educational value that goes far beyond goal setting and self-assessment.

\subsection{Learner autonomy}

Ultimately, the CEFR's focus on the individual language user/learner as a social agent derives from the Council of Europe's foundational values: human rights, democratic governance and the rule of law. The purpose of the European Convention on Human Rights (1950) is to protect the autonomy of the individual citizen; while the Council of Europe's education policies are designed to prepare citizens 
to participate actively in the democratic process by developing their capacity for autonomous learning and critical thinking. Because it is a transnational organization, the Council has been especially interested in language education. The European Cultural Convention (1954) seeks to "develop mutual understanding among the peoples of Europe and reciprocal appreciation of cultural diversity" and to "encourage $[\ldots]$ the study of the languages, history and civilization" of the countries that are party to the Convention. ${ }^{2}$ It is only as a result of effective language learning that critical thinking and democratic participation can transcend the limits of the monolingual nation state. Thus, for more than half a century the Council of Europe's work in language education has focused on the individual learner's communicative needs, the development of language learning skills that can be deployed outside formal education, and the encouragement of lifelong language learning. The Council's earliest modern languages projects were carried out under the aegis of the Committee for Out-of-School Education, which assigned a central role to "responsible autonomy" (Janne 1977: 17); and it was the Council of Europe that introduced the concept of learner autonomy to language education via Henri Holec's report Autonomy and Foreign Language Learning (1979).

Acknowledging that learners are "the persons ultimately concerned with language acquisition and learning processes", the CEFR stresses the importance of autonomous learning, especially in a lifelong perspective:

Autonomous learning can be promoted if "learning to learn" is regarded as an integral part of language learning, so that learners become increasingly aware of the way they learn, the options open to them and the options that best suit them. Even within the given institutional system they can then be brought increasingly to make choices in respect of objectives, materials and working methods in the light of their own needs, motivations, characteristics and resources (Council of Europe 2001: 141f.).

The ELP was designed to support this process of "learning to learn", which is seen here as an additional feature of the language learning process. An altogether more profound understanding of language learner autonomy is, however, licensed by the CEFR's summary of its action-oriented approach:

\footnotetext{
${ }^{2}$ https://www.coe.int/en/web/conventions/full-list/-/conventions/treaty/018 [01.03.2019].
} 
Language use, embracing language learning, comprises the actions performed by persons who as individuals and as social agents develop a range of competences, both general and in particular communicative language competences. They draw on the competences at their disposal in various contexts under various conditions and under various constraints to engage in language activities involving language processes to produce and/or receive texts in relation to themes in specific domains, activating those strategies which seem most appropriate for carrying out the tasks to be accomplished. The monitoring of these actions by the participants leads to the reinforcement or modification of their competences (Council of Europe 2001: 9; the words and phrases in italics, to which "contexts" in the second sentence should be added, refer to the principal dimensions of the CEFR's descriptive scheme).

According to this summary, language learning is a variety of language use in the sense that proficiency develops from sustained interaction between the learner's gradually developing competences and the communicative tasks whose performance requires him or her to use the target language. The last sentence of the summary deserves special attention: "The monitoring of these actions by the participants leads to the reinforcement or modification of their competences." The CEFR defines monitoring as the strategic component that "deals with updating of mental activities and competences in the course of communication" (Council of Europe 2001: 92); as such it plays a crucial role in language use. But monitoring is also the metacognitive mechanism that enables us to exercise strategic control over the language learning process (Little 1996). Thus, the CEFR's summary of its action-oriented approach carries two strong implications. First, if learners are to develop a proficiency that allows them to act as individuals and social agents, the target language should be the principal medium of their learning; and secondly, in formal contexts their learning should be managed in ways that are designed to exercise and further develop the metacognitive and metalinguistic processes of monitoring. According to this interpretation, the CEFR's action-oriented approach encourages the development of a proficiency that is both communicative and metacognitive. It implies a pedagogical approach in which the target language is the principal channel of the learners' agency, the communicative and metacognitive medium through which, individually and collaboratively, they plan, execute, monitor and evaluate their own learning (for an extended version of this argument, see Little et al. 2017, also Little \& Erickson 2015). The ELP offers language learners a means of organizing and reflecting on their learning that recalls the radical learnercentredness of the Council of Europe's adult education project of the 1970s (see Little 2017b). 


\subsection{Plurilingualism and pluriculturalism}

Besides supporting autonomous learning, the ELP is intended to foster the development of plurilingualism and pluriculturalism as a lifelong process (Council of Europe 2011: 4). Learner autonomy was already present in the Council of Europe's earliest work on language education; and the organization's interest in the (inter) cultural dimension of language learning dates back to the European Cultural Convention. Plurilingualism, by contrast, made its first appearance in the CEFR, where it is introduced in these terms:

[T] he plurilingual approach emphasises the fact that as an individual person's experience of language in its cultural contexts expands, from the language of the home to that of society at large and then to the languages of other peoples (whether learnt at school or college, or by direct experience), he or she does not keep those languages and cultures in strictly separated mental compartments, but rather builds up a communicative competence to which all knowledge and experience of languages contributes, and in which languages interrelate and interact (Council of Europe 2001: 4).

Since the publication of the CEFR, the Council of Europe's work in language education has included the project Languages in Education/Languages for Education, which developed the concept of "plurilingual and intercultural education" (Cavalli et al. 2009, Coste et al. 2009). This embraces all the languages present in a given school: the language of instruction, which in most countries is also taught as a subject in its own right; modern foreign and classical curriculum languages; and minority languages of all kinds, whether or not they are taught at school. We may think that the Principles and Guidelines go too far in describing the ELP as "a tool to promote plurilingualism and pluriculturalism" (Council of Europe 2011: 5); but it "values the full range of the learner's language and intercultural competence and experience regardless of whether acquired within or outside formal education" (Council of Europe 2011: 5) and thus can be used to promote awareness of a developing plurilingual repertoire and reflection on the relation between its component languages.

As we have seen, one of the principal aims of the European Cultural Convention is to promote mutual understanding and cultural exchange. The ELP's focus on the cultural dimension of language learning is thus to be expected. The Council of Europe's tendency to associate cultures with countries has been criticized as "naïve and positivistic" (Dervan 2016: 76); and my own reflection on the concept of plurilingualism criticizes the assumption that the development of plurilingual repertoires in formal contexts of learning necessarily entails engagement with new cultures that are characterized by their "otherness" (Little 2019). But while we may reject cultural essentialism, it is beyond dispute that many aspects of culture are linguistically bound. They may, for example, be made of language, like broadcast 
and print media or works of literature; they may determine the ways in which language is used, like politeness conventions; and they may be part of the unconscious fabric of the language, like the involuntary gestures that accompany speech and seem to reflect the deepest cognitive structures of language. Reflective language learning inevitably engages with these features.

It should be clear from this brief discussion of the ELP's three pedagogical focuses that it posed a formidable challenge to language learning and teaching in all educational domains and at all levels. Section 4 will elaborate on that challenge in an attempt to explain why, despite an enthusiastic reception to begin with, the ELP failed to put down secure roots in the education systems of Council of Europe member states. But first I shall describe the only ELP project I am aware of that succeeded at national level.

\section{An example of early success: the inclusion of immigrant pupils in Irish primary education}

\subsection{The context}

Since the late 1990s, Ireland has experienced unprecedented levels of immigration that have brought with them the challenge of including in the school system relatively large numbers of children and adolescents from non-English-speaking families. From 2000 to 2008, Integrate Ireland Language and Training (IILT), a not-for-profit campus company of Trinity College Dublin, was funded by the Irish government to provide intensive English language programmes for adult refugees and to support the teaching of English as an Additional Language (EAL) in Irish schools (I was non-stipendiary director of IILT for the eight years of its existence). The Department of Education gave IILT three tasks in relation to the school sector: to analyse the language needs of non-English-speaking pupils at primary and students at post-primary level; to develop learning materials and other resources to support their learning of English; and to mediate those materials and resources to teachers via regular in-service days. In due course IILT also developed, piloted and published an assessment kit so that schools could use a common tool to gauge the progress of their EAL pupils/students.

\subsection{English Language Proficiency Benchmarks}

The English Language Proficiency Benchmarks are IILT's analysis of the language needs of EAL learners. Separate versions were developed for the primary and post-primary sectors; here I focus on the former (Integrate Ireland Language and Training 2003). When IILT was assigned its tasks, the Department of Education had already introduced the policy of funding two years of English language support for EAL 
learners. Schools were free to deliver the support in whatever way seemed to them most appropriate, but there was a general expectation that EAL learners would be assigned to an age-appropriate mainstream class and withdrawn regularly, typically once a day, for special instruction in English.

It made sense for IILT's needs analysis to focus on the two years of language support and to provide not a separate curriculum for EAL but a description of the extent to which EAL learners could participate in mainstream classroom learning at different levels of proficiency. The first three levels of the CEFR provided a ready basis for such a description. It seemed reasonable to assume that two years of effective English language support delivered in the context of immersion could bring EAL learners to B1, the level at which they would be able to act as independent agents. IILT intended the Benchmarks to be used by teachers on a daily basis. This meant that they must be relatively brief, easy to understand and easy to apply to EAL learners and the content and processes of English language support. For this reason, the basic design of the Benchmarks follows that of the CEFR's selfassessment grid (Council of Europe 2001: 26f.): the language activities of listening, reading, spoken interaction, spoken production and writing on the vertical axis and the proficiency levels (A1, A2 and B1) on the horizontal. It was also necessary to establish clear and practical links with the curriculum. Because the Irish primary curriculum is designed to provide an integrated learning experience and begins to distinguish between separate curriculum subjects only in the senior grades, IILT decided to focus on recurrent curriculum themes. Accordingly, the Benchmarks comprise a minimum of explanatory text and fifteen grids: global benchmarks of communicative proficiency, global scales of underlying linguistic competence (grammar, vocabulary, phonology, orthography) and thirteen "units of work": Myself; Our school; Food and clothes; Colours, shapes and opposites; People who help us; Weather, Transport and travel; Seasons, holidays and festivals; The local and wider community; Time; People and places in other areas; Animals and plants; Caring for my locality. By way of illustration, Table 1 brings together descriptors for spoken interaction from the CEFR's self-assessment grid, the global benchmarks and the unit of work People who help us. 
Table 1: Descriptors for spoken interaction from the CEFR's self-assessment grid and the primary version of the English Language Proficiency Benchmarks

\begin{tabular}{|c|c|c|c|}
\hline & A1 & A2 & B1 \\
\hline $\begin{array}{l}\text { Self- } \\
\text { assess- } \\
\text { ment grid, } \\
\text { CEFR } \\
\text { (Council } \\
\text { of } \\
\text { Europe, } \\
\text { 2001: 26) }\end{array}$ & $\begin{array}{l}\text { I can interact in a } \\
\text { simple way provided } \\
\text { the other person is } \\
\text { prepared to repeat or } \\
\text { rephrase things at a } \\
\text { slower rate of speech } \\
\text { and help me formulate } \\
\text { what I'm trying to say. } \\
\text { I can ask and answer } \\
\text { simple questions in } \\
\text { areas of immediate } \\
\text { need or on very } \\
\text { familiar topics. }\end{array}$ & $\begin{array}{l}\text { I can communicate in } \\
\text { simple and routine } \\
\text { tasks requiring a } \\
\text { simple and direct } \\
\text { exchange of } \\
\text { information on } \\
\text { familiar topics and } \\
\text { activities. I can handle } \\
\text { very short social } \\
\text { exchanges, even } \\
\text { though I can't usually } \\
\text { understand enough to } \\
\text { keep the conversation } \\
\text { going myself. }\end{array}$ & $\begin{array}{l}\text { I can deal with most } \\
\text { situations likely to arise } \\
\text { whilst travelling in an } \\
\text { area where the } \\
\text { language is spoken. I } \\
\text { can enter unprepared } \\
\text { into conversation on } \\
\text { topics that are familiar, } \\
\text { of personal interest or } \\
\text { pertinent to everyday } \\
\text { life (e.g., family, } \\
\text { hobbies, work, travel } \\
\text { and current events). }\end{array}$ \\
\hline $\begin{array}{l}\text { Global } \\
\text { bench- } \\
\text { marks } \\
\text { (IILT } \\
\text { 2003) }\end{array}$ & $\begin{array}{l}\text { Can greet, say please } \\
\text { and thank you, and ask } \\
\text { for directions to } \\
\text { another place in the } \\
\text { school. } \\
\text { Can respond non- } \\
\text { verbally to basic direc- } \\
\text { tions to a place in the } \\
\text { school when the other } \\
\text { person supplements } \\
\text { speech with signs or } \\
\text { gestures. } \\
\text { Can give simple } \\
\text { answers to basic ques- } \\
\text { tions when given time } \\
\text { to reply and the other } \\
\text { person is prepared to } \\
\text { help. } \\
\text { Can make basic } \\
\text { requests in the class- } \\
\text { room or playground } \\
\text { (e.g., for the loan of a } \\
\text { pencil) and respond } \\
\text { appropriately to the } \\
\text { basic requests of } \\
\text { others. }\end{array}$ & $\begin{array}{l}\text { Can ask for attention } \\
\text { in class. } \\
\text { Can greet, take leave, } \\
\text { request and thank } \\
\text { appropriately. } \\
\text { Can respond with } \\
\text { confidence to familiar } \\
\text { questions clearly } \\
\text { expressed about fami- } \\
\text { ly, friends, school } \\
\text { work, hobbies, holi- } \\
\text { days, etc., but is not } \\
\text { always able to keep the } \\
\text { conversation going. } \\
\text { Can generally sustain a } \\
\text { conversational } \\
\text { exchange with a peer } \\
\text { in the classroom when } \\
\text { carrying out a collabo- } \\
\text { rative learning activity } \\
\text { (making or drawing } \\
\text { something, preparing a } \\
\text { role-play, presenting a } \\
\text { puppet show, etc.). } \\
\text { Can express personal } \\
\text { feelings in a simple } \\
\text { way. }\end{array}$ & $\begin{array}{l}\text { Can speak with fluency } \\
\text { about familiar topics } \\
\text { such as school, family, } \\
\text { daily routine, likes and } \\
\text { dislikes. } \\
\text { Can engage with other } \\
\text { pupils in discussing a } \\
\text { topic of common inter- } \\
\text { est (songs, football, } \\
\text { pop stars, etc.) or in } \\
\text { preparing a } \\
\text { collaborative classroom } \\
\text { activity. } \\
\text { Can keep a conversa- } \\
\text { tion going, though } \\
\text { he/she may have some } \\
\text { difficulty making } \\
\text { him/herself } \\
\text { understood from time } \\
\text { to time. } \\
\text { Can repeat what has } \\
\text { been said and convey } \\
\text { the information to } \\
\text { another person. }\end{array}$ \\
\hline
\end{tabular}




\begin{tabular}{|c|c|c|c|}
\hline & A1 & A2 & B1 \\
\hline $\begin{array}{l}\text { Unit of } \\
\text { work } \\
\text { People } \\
\text { who help } \\
\text { us }\end{array}$ & $\begin{array}{l}\text { Can use gestures, key } \\
\text { words and simple } \\
\text { phrases/sentences to } \\
\text { ask for help (e.g., in } \\
\text { Stay Safe role-plays) } \\
\text { Can reply using key } \\
\text { words and simple } \\
\text { phrases/sentences to } \\
\text { basic questions about } \\
\text { the jobs of people who } \\
\text { can help (e.g., Where do } \\
\text { we find a ...? What does } \\
\text { be/she do?). }\end{array}$ & $\begin{array}{l}\text { Can ask and answer } \\
\text { questions about what } \\
\text { people in familiar roles } \\
\text { do in their jobs. } \\
\text { Can talk with the } \\
\text { teacher or another } \\
\text { pupil about personal } \\
\text { experiences with } \\
\text { people in roles of } \\
\text { responsibility (e.g., } \\
\text { visit to doctor, parent } \\
\text { is a nurse/doctor, } \\
\text { school traffic warden, } \\
\text { postman). }\end{array}$ & $\begin{array}{l}\text { Can ask and answer } \\
\text { questions about differ- } \\
\text { ent jobs and responsi- } \\
\text { bilities. } \\
\text { Can ask questions of a } \\
\text { speaker who has been } \\
\text { invited to the school to } \\
\text { talk about his/her job. } \\
\text { Can answer typical } \\
\text { questions that may be } \\
\text { asked by a person in } \\
\text { responsibility (e.g. in } \\
\text { role-plays involving } \\
\text { emergencies, danger, } \\
\text { etc.). }\end{array}$ \\
\hline
\end{tabular}

\subsection{European Language Portfolio}

IILT then developed a version of the ELP for primary EAL learners (IILT 2004), with "I can" checklists derived from the Benchmarks and organized according to curriculum themes. Each learner's ELP provided up-to-date evidence of his or her progress: pages in the language passport and language biography were gradually filled in, samples of work were stored in the dossier and the checklists were used for regular teacher-supported self-assessment. EAL pupils' plurilingualism and pluriculturalism were also accommodated. Because the Benchmarks seek to describe the development of EAL learners' capacity to participate in curriculum learning, most descriptors refer to the language activities characteristic of Irish primary and post-primary classrooms in relation to curriculum content. They nevertheless assume that cultural similarities and differences will be acknowledged and discussed. In the Benchmarks unit Seasons, holidays and festivals, for example, one of the B1 descriptors for spoken interaction reads as follows: "Can describe and respond to questions about what takes place during a festival or celebration in his/her family or community". Designed exclusively for primary pupils whose home language is neither English nor Irish, the ELP makes space for all the languages that the individual learner knows and encourages reflection on similarities and differences between life in Ireland and life as he or she has experienced it elsewhere.

Primary schooling in Ireland comprises two Infant years, which are equivalent to pre-school in other countries, and six grades or classes. In most schools, pupils are introduced to environmental print from the beginning and to reading and writing in Senior Infants. The ELP assumes that learners have acquired at least basic literacy skills, and although some teachers used it to support the development 
of reading and writing, it was largely inaccessible to pupils in the Junior and Senior Infant grades. My First English Book was designed to fill the gap: a workbook that encouraged pre-literate pupils to reflect on their learning of English and record their progress by colouring in charts and images.

In each of the last two years of IILT's existence, the organization distributed 5000 copies of the primary ELP and 2000 copies of My First English Book; in other words, they were used by a majority of EAL pupils nationwide. Both tools were valued pedagogically because they helped teachers to organize English language support and raised pupils' awareness of their developing proficiency. They also served an important documentary function, informing class teachers, principals, school inspectors and parents of the individual pupil's progress. Together, the Benchmarks, the ELP and My First English Book provided a firm basis on which to develop other supports.

\subsection{An assessment kit}

One of the intended functions of the Benchmarks and the ELP was to help schools to monitor the progress of their EAL pupils; but from an early stage, language support teachers expressed a need for more finely tuned assessment instruments. They wanted to be able to identify specific weaknesses in individual learners' proficiency, measure their progress at the end of their first and second years of English language support and in some cases, use the evidence of formal tests to argue for an extension of language support. IILT responded by developing assessment kits based on the primary and post-primary Benchmarks (Little et al. 2007a, 2007b). Each kit had four sections - listening, reading, speaking and writing. Assessment tasks were derived from Benchmarks descriptors; listening and reading tasks were designed with an inbuilt scoring scheme; and rating grids were provided for speaking and writing tasks. The various sections of the kits were developed, presented at in-service days and piloted prior to publication in 2007. The piloting of the primary kit involved 50 schools and the analysis of a significant body of data; teachers achieved a high level of accuracy and consistency in rating their own pupils.

\subsection{Concluding remarks}

The success of this project seems to have been due to three factors. First, the Benchmarks and ELP filled a vacuum: EAL teachers had no other resources that were tailored to the demands of the Irish situation. Secondly, over a period of seven years IILT developed further materials in interaction with the teachers who attended twice-yearly in-service seminars. And thirdly, the Benchmarks proved to be an accurate reflection of reality: empirical research confirmed that when they were immersed in a mainstream class and provided with additional English language support, immigrant pupils could progress from zero to B1 in two years (Ćatibušić \& Little 2014). 
Funding was withdrawn from IILT in the summer of 2008, for complex reasons (Little \& Lazenby Simpson 2009: 121f.). Without the regular support provided by in-service seminars, the Benchmarks, ELPs and other materials quickly fell out of use, though the Department of Education continued to use the tests for a number of years. All materials are still available, however, from the website of the National Council for Curriculum and Assessment. ${ }^{3}$ IILT's approach to adapting the CEFR seems not to have been replicated in other countries, though the English Language Proficiency Benchmarks provided a model for the development of the Council of Europe's Curriculum Framework for Romani ${ }^{4}$, which was used to guide the development of two ELPs, for learners aged 6-11 and 11-16, and teaching materials in six varieties of Romani. ${ }^{5}$

\section{Why was the ELP not more successful in European schools?}

As noted above, the ELP was welcomed with enthusiasm when it was first launched in 2001, and 118 ELPs were developed and validated between 2000 and 2010; but I have been unable to find evidence of large-scale adoption and use except for the example I have just given. In my view there are four reasons for this.

\subsection{Inadequate support}

When the ELP was first launched, in 2001, there was a widespread expectation that it would be a "magic bullet", spontaneously providing a universal remedy for the ills of language teaching and learning across the continent. To enthusiasts it seemed to offer everything that language education most needed, and some of them clearly believed that if only an ELP could be put into the hands of every learner its impact would be unstoppable. This may help to explain why, when funding was provided for ELP development, it sometimes failed to provide for the preparation of teachers and rarely lasted beyond the pilot phase (Stoicheva et al. 2009). In most countries ELP implementation needed much more support than the authorities were prepared to provide.

\subsection{ELP's pedagogical functions not widely adopted}

The ELP's pedagogical functions were and perhaps remain alien to the majority of European education systems. In many countries curricula emphasize the importance of critical thinking and independent learning, but the practice of learner

\footnotetext{
${ }^{3}$ http://www.ncca.ie [01.03.2019].

${ }^{4}$ http://www.coe.int/lang [01.03.2019].

${ }^{5}$ http://qualirom.uni-graz.at [01.03.2019].
} 
autonomy in school classrooms remains a minority pursuit (for a detailed description and empirical exploration of autonomous language learning, see Little et al. 2017). Autonomous learning demands changes in teaching approaches and classroom discourse that are evidently beyond the majority of teachers and educational administrators. In much the same way, the wealth of theoretical and practical work that has focused on intercultural awareness and the development of intercultural competence (e.g. Alred et al. 2006, Byram 1997, 2008) seems to have had little impact on what happens in most L2 classrooms. And although the concept of plurilingualism has been central to the Council of Europe's work in language education since the publication of the CEFR (see, for example, Cavalli et al. 2009, Coste et al. 2009), it has still to be widely adopted as a key educational goal; most L2 education in Europe and beyond continues to focus on individual languages in isolation from one another rather than on the development of learners' plurilingual repertoires.

\subsection{The problem of integration}

The ELP ran into problems of integration in at least three ways. Most models were not developed as part of a larger project of curriculum reform, which meant that the checklists of "I can" descriptors were often difficult for teachers and learners to relate to curriculum goals, especially when the latter were not expressed in functional terms. A further difficulty arose from the fact that most L2 classrooms work with a textbook (in many countries it is obligatory to do so), and teachers were faced with a great deal of extra work if they wanted to use the ELP and the textbook in tandem with each other. Also, the CEFR and ELP imply an assessment culture in which learners themselves are active agents via self-assessment (Little \& Erickson 2015), whereas in most educational systems such a culture is wholly unknown. The movement towards Assessment for Learning in the UK (e.g. ARG 1999, Black \& Wiliam 2006, James \& Pedder 2006) might seem to provide a counter example, but closer examination shows that it allows only limited scope for the exercise of learner agency (see Little et al. 2017: 97-99).

\subsection{Problems with the model}

As it is defined in the Principles and Guidelines (Council of Europe 2000, 2011), the ELP is itself not without contradictions. For example, we have seen that the CEFR defines L2 proficiency in terms that imply a key role for target language use in the language classroom; and if the reflective processes of planning, monitoring and evaluation are to be part of target language use, it makes sense to provide learners with "I can" checklists in the language(s) they are learning. This, however, may be thought to work against the principle of plurilingualism because checklists in several different languages may reinforce the tendency to see them as entirely separate from one another. On the other hand, providing checklists in the language 
of schooling may support plurilingualism while working against reflective target language use. Also, as it is defined in the Principles and Guidelines the ELP provides a comprehensive embodiment of the Council of Europe's political, cultural and educational ethos, but it seems unlikely that any one context of learning will be able to respond equally to all dimensions of that ethos. What is more, in many circumstances the tripartite structure of the ELP - language passport, language biography, dossier - is simply too "heavy" to be easily accommodated to regular classroom use. In an earlier article (Little 2012b), I suggested that it might be wise to redevelop the ELP as two separate but closely related documents. One would focus on the learning of individual languages, using checklists of "I can" descriptors to promote reflective learning and learner autonomy; the other would be used collaboratively by all language teachers in a school to help their learners to reflect on their developing plurilingual repertoires and intercultural awareness.

\section{The challenge of the CEFR Companion Volume}

The ELP was conceived and pilot models were trialled in parallel with the development of the 2001 version of the CEFR. Work on the 2018 CEFR Companion Volume (CV) was not accompanied by a movement to revive the ELP, but the CV is driven by the same political, cultural and educational agenda as the CEFR. If in 2001 the CEFR was needed to help intensify "language learning and teaching in member countries [...] in the interests of greater mobility, more effective international communication combined with respect for identity and cultural diversity, better access to information, more intensive personal interaction, improved working relations and a deeper mutual understanding" (Council of Europe 2001: 5), the same is true of the CV in 2018. By the same token, if in 2001 the ELP was deemed an appropriate means of mediating to language learners the Council of Europe's ethos and values and the CEFR's understanding of language learning as language use, some version of the same instrument remains appropriate in 2018.

In its introductory discussion of key aspects of the CEFR, the CV emphasizes that the CEFR's descriptive scheme and action-oriented approach put the coconstruction of meaning at the centre of the learning and teaching process (Council of Europe 2018: 27). Besides coinciding closely with the pedagogical approach summarized in section 2.2 above, this argument is given additional weight by the CV's principal innovation, its extensive treatment of mediation understood as a process in which "the user/learner acts as a social agent who creates bridges and helps to construct or convey meaning, sometimes within the same language, sometimes from one language to another" (Council of Europe 2018: 99). The CV provides a total of twenty-four scales for mediation activities and mediation strategies. Taken together, they offer a broad description of the communicative behaviour that the Council of Europe's core values demand of the plurilingual language user/learner. They also describe the capacities required of language teachers if they 
are to operationalize the CEFR's action-oriented dynamic in their classrooms. As Little et al. (2017) argue, such a dynamic is fundamental to the development of learner autonomy. If the ELP, in one or another revised version, still has a role to play, it will have a better chance of success if its use is framed by an understanding of language learning and teaching informed by the CV's treatment of mediation.

The CV updates the CEFR's illustrative scales in four ways. First, the 2001 scales have been enriched by the addition of calibrated descriptors from multiple sources, especially at levels A1, C1 and C2, which greatly strengthens their range and depth. Secondly, three new scales have been added, for Reading as a leisure activity, Using telecommunications and Sustained monologue: giving information. Thirdly, the 2001 scale for phonological control has been replaced by three new scales, for Overall phonological control, Sound articulation and Prosodic features. And fourthly, descriptors have been included for a new pre-A1 level. In addition, the CV provides three scales for plurilingual and pluricultural competence: Building on pluricultural repertoire, Plurilingual comprehension and Building on plurilingual repertoire.

The CV seems particularly apt to support a revival of the functionality of the ELP linked to the redevelopment of curricula and assessment. It explains how to create a curriculum by drawing up a needs profile for a given group of learners and then defining communicative aims in four steps (Council of Europe 2018: 42): (i) the descriptor scales are selected that coincide with the needs profile; (ii) in consultation with stakeholders and teachers (and in some cases the learners themselves), a target level is determined for each selected scale; (iii) the descriptors for the target level(s) are compiled in a list; and (iv) the list is refined on the basis of further consultation. Having reached this point, it would be possible to arrange the list in a series of grids similar to those in the English Language Proficiency Benchmarks described in section 3.2. As the Irish example shows, this kind of curriculum framework provides teachers with practical assistance, and it could also be used to inform all but the very youngest learners. From here it would be relatively straightforward to create goal-setting and self-assessment checklists and to structure a learning portfolio appropriate to the learners in question. Whether the portfolio should retain the three obligatory components of the ELP is a moot question. Some form of language biography is clearly essential to provide a reflective accompaniment to learning and support the recurrent cycle of goal setting and self-assessment; and a dossier is an obvious way of storing both work in progress and work that can be used to support self-assessment claims. But a version of the language passport might be used for a reporting function only. In a school system, for example, students might need different curriculum frameworks and portfolios for first, second and subsequent foreign languages but could use the same language passport to summarize their learning achievement at the end of schooling. 


\section{Conclusion}

As the Principles and Guidelines (Council of Europe 2000, 2011) show, the ELP embodies cultural and educational values that flow directly from the Council of Europe's human rights agenda. The same values underpin the CEFR, and the publication of its 2018 Companion Volume challenges language educators to revisit the ELP and explore ways of reviving its core functionalities. In principle this should not be difficult. Learner autonomy remains a widespread curricular goal and a major theme in the language learning literature, and in some quarters the ELP is still considered a self-evident support for reflective learning in which selfassessment plays a central role. What is more, the Council of Europe and the European Centre for Modern Languages continue to maintain ELP websites that offer a wealth of relevant material ${ }^{6}$; and the latter organization's current interest in language learning pathways includes a focus on learner self-management and selfassessment that implies the possibility of a renewed role for the ELP. In practice, however, if the ELP is to make a successful return, in new versions tailored to the needs of specific contexts, it will have to overcome the many difficulties that undermined earlier attempts at ELP implementation. Realistically, there is little hope for an ELP revival at the level of national school systems: the cost of persuading, preparing and supporting teachers would simply be too great. Much could no doubt be achieved by local and regional school networks if they were provided with the necessary financial support, but these days funding is always in short supply. The outlook may be more positive in the university sector. CercleS (European Confederation of Language Centres in Higher Education) has long supported use of the CEFR and ELP, and individual universities have the freedom to redesign their language curricula, teaching/learning and assessment according to the principles of constructive alignment. In the end, we must recognize that largescale educational reform of the kind envisaged by the Council of Europe is always highly problematic. Despite its major impact on language testing, the CEFR remains little known among language education professionals at all levels. The same is true of the ELP, and history suggests that those who make use of the CEFR's Companion Volume in the way I have outlined will be the happy few.

\section{References}

Alred, Geof; Byram, Michael; Fleming, Mike (eds.) (2006): Education for Intercultural Citizenship. Concepts and Comparisons. Clevedon: Multilingual Matters.

ARG (Assessment Reform Group) (1999): Assessment for Learning: Beyond the Black Box. Cambridge: University of Cambridge, School of Education.

\footnotetext{
${ }^{6}$ http://www.coe.int/portfolio [01.03.2019].
} 
Biggs, John; Tang, Catherine (2011): Teaching for Quality Learning at University. Fourth edition. Maidenhead: Open University Press.

Black, Paul; Wiliam, Dylan (2006): Assessment and classroom learning. In: Gardner, John (ed.): Assessment and Learning. London: Sage, 9-25.

Byram, Michael (1997): Teaching and Assessing Intercultural Communicative Competence. Clevedon: Multilingual Matters.

Byram, Michael (2008): From Foreign Language Education to Education for Intercultural Citizenship: Essays and Reflections. Clevedon: Multilingual Matters.

Byram, Michael; Parmenter, Lynne (2012): The Common European Framework of Reference. The Globalisation of Language Education Policy. Bristol: Multilingual Matters.

Ćatibušić, Bronagh; Little, David (2014): Immigrant Pupils Learn English: A CEFRrelated Empirical Study of L2 Development (English Profile Studies 3). Cambridge: Cambridge University Press.

Cavalli, Marisa; Coste, Daniel; Crisan, Alexandru; van de Ven, Piet-Hein (2009): Plurilingual and Intercultural Education as a Project. Strasbourg: Council of Europe.

Coste, Daniel; Cavalli, Marisa; Crisan, Alexandru; van de Ven, Piet-Hein (2009): Plurilingual and Intercultural Education as a Right. Strasbourg: Council of Europe.

Council of Europe (1996): Modern Languages: Learning, Teaching, Assessment. A Common European Framework of Reference. Draft 2 of a Framework proposal. Strasbourg: Council of Europe.

Council of Europe (1997): European Language Portfolio: Proposals for Development. With contributions by I. Christ; F. Debyser; A. Dobson; R. Schärer; G. Schneider; B. North; J. Trim. Strasbourg: Council of Europe.

Council of Europe (2000): European Language Portfolio: Principles and Guidelines. Strasbourg: Council of Europe.

Council of Europe (2001): Common European Framework of Reference for Languages: Learning, Teaching, Assessment. Cambridge: Cambridge University Press.

Council of Europe (2011): European Language Portfolio: Principles and Guidelines, with added explanatory notes. Strasbourg: Council of Europe. https://rm.coe.int/16804586ba [01.03.2019].

Council of Europe (2018): CEFR Companion Volume with New Descriptors. Strasbourg: Council of Europe. https://rm.coe.int/cefr-companion-volume-withnew-descriptors-2018/1680787989 [01.03.2019].

Dervan, Fred (2016): Interculturality in Education. A Theoretical and Methodological Toolbox. London: Palgrave Macmillan.

Holec, Henri (1979): Autonomy and Foreign Language Learning. Strasbourg: Council of Europe. Republished 1981, Oxford: Pergamon. 
Integrate Ireland Language and Training (2003): English Language Proficiency Benchmarks for Non-English-speaking Pupils at Primary Level. Dublin: Integrate Ireland Language and Training. https://www.ncca.ie/ $\rightarrow$ EAL [01.03.2019].

Integrate Ireland Language and Training (2004): European Language Portfolio (Primary): Learning the Language of the Host Community. Dublin: Integrate Ireland Language and Training. https://www.ncca.ie/ $\rightarrow$ EAL [01.03.2019].

James, Mary; Pedder, David (2006): Professional learning as a condition for assessment for learning. In: Gardner, John (ed.): Assessment and Learning. London: Sage, 27-43.

Janne, Henri (1977): Organisation, Content and Methods of Adult Education (CCC/EES (77) 3-E). Strasbourg: Council of Europe.

Little, David (1996): Strategic competence considered in relation to strategic control of the language learning process. In: Holec, Henri; Little, David; Richterich, René: Strategies in Language Learning and Use. Studies towards a Common European Framework of Reference for Language Learning and Teaching. Strasbourg: Council of Europe, 9-37.

Little, David (2011): The Common European Framework of Reference for Languages, the European Language Portfolio, and language learning in higher education. In: Language Learning in Higher Education 1/1, 1-21.

Little, David (2012a): The Common European Framework of Reference for Languages and the European Language Portfolio: Some history, a view of language learner autonomy, and some implications for language learning in higher education. In: Language Learning in Higher Education 2/1, 1-16.

Little, David (2012b): The European Language Portfolio: history, key concerns, future prospects. In: Kühn, Bärbel; Pérez Cavana, Maria (eds.): Perspectives from the European Language Portfolio. London; New York: Routledge, 7-21.

Little, David (2017a): Responding to the challenge of student diversity: learner autonomy and constructive alignment. In: Harsch, Claudia; Krings, Hans P.; Kühn, Bärbel (eds.): Inhalt und Vielfalt - Neue Herausforderungen für das Sprachenlernen und -lehren an Hochschulen, Erträge des 5. Bremer Symposiums. Bochum: AKS-Verlag, 13-29.

Little, David (2017b): Three versions of learner autonomy and their implications for English-medium degree programmes. In: Breeze, Ruth; Sancho Guinza, Carmen (eds.): Essential Competencies for English-medium University Teaching. Cham: Springer International Publishing, 145-157.

Little, David (2019): Plurilingual and intercultural education: some critical reflections. In: Huhta, Ari; Erickson, Gudrun; Figueras, Neus (eds.): Developments in Language Education. A Memorial Volume in Honour of Sauli Takala. EALTA and University of Jyväskylä, 226-238. 
Little, David; Dam, Leni; Legenhausen, Lienhard (2017): Language Learner Autonomy: Theory, Practice and Research. Bristol: Multilingual Matters.

Little, David; Erickson, Gudrun (2015): Learner identity, learner agency, and the assessment of language proficiency: some reflections prompted by the Common European Framework of Reference for Languages. In: Annual Review of Applied Linguistics 35, 120-139.

Little, David; Goullier, Francis; Hughes, Gareth (2011): The European Language Portfolio. The story so far (1991-2011). Strasbourg: Council of Europe.

Little, David; Lazenby Simpson, Barbara (2009): Teaching immigrants the language of the host community: Two object lessons in the need for continuous policy development. In: Alderson, J. Charles (ed.): The Politics of Language Education: Individuals and Institutions. Bristol: Multilingual Matters, 104-124.

Little, David; Lazenby Simpson, Barbara; Finnegan Ćatibušić, Bronagh (2007a): Primary School Assessment Kit. Dublin: Department of Education and Science.

Little, David; Lazenby Simpson, Barbara; Finnegan Ćatibušić, Bronagh (2007b): English as an Additional Language. Post-primary Assessment Kit. Dublin: Department of Education and Science.

Schärer, Rolf (2000): European Language Portfolio. Final Report on the Pilot Projects. Strasbourg: Council of Europe. https:/ / rm.coe.int/16804586bb [01.03.2019].

Stoicheva, Maria; Hughes, Gareth; Speitz, Heike (2009): The European Language Portfolio: An Impact Study. Strasbourg: Council of Europe. https://rm.coe.int/16804595a9 [01.03.2019]. 